\title{
ESEJI
}

BOJAN B. DIMITRIJEVIĆ, naučni savetnik

Institut za savremenu istoriju

Beograd, Trg Nikole Pašića 11

UDK 355:929 Михаиловић Д.

94(497.1)"1941/1945"

343.322(497.1)"1946"

\section{SVEDOČENJE O SUĐENJU I SPORNOJ KOLABORACIJI ĐENERALA MIHAILOVIĆA ${ }^{* 1}$}

Bavio sam se istraživanjem biografije generala Mihailovića i u okviru tog istraživanja imao sam prilike da vidim i ono što je vezano za njegovo suđenje. Proučavajući njegovu vojnu karijeru pre 1941. godine i karijeru posle 1941. imao sam mogućnost da vidim raspoloživu dokumentaciju koja je sačuvana u domaćim arhivama kao i onu koja je u tim arhivama dobijena iz inostranih arhiva. Takođe, imao sam prilike da razgovaram sa porodicom gen. Mihailovića, sinom i drugim naslednicima, tokom 1994. i 1995. godine. Kao član Državne komisije koja je utvrđivala okolnosti i mesto streljanja gen. Mihailovića u Arhivu BIA-e odnosno delimično u Arhivu Srbije video sam i onu istorijsku građu koja je relevantna za njegovo zarobljavanje i za njegovo suđenje. Delovi njegovih ispisa čuvaju se, čini mi se, sada u Arhivu Srbije. Takođe, kao istoričar, proučavao sam dotično suđenje, ali moram da se ogradim da sam profesionalni istoričar i nije mi poznat pravni kontekst tog suđenja, ali na bazi istorijskih činjenica ustanovio sam svoje mišljenje o tome. Takođe, imao sam prilike da pročitam, a i priredim za štampu, iskaz gen. Mihailovića u istrazi pred organima UDB-e za Srbiju koja je izvršena u aprilu i maju 1946. godine.

Kao posebno ističem, jer sam želeo da ustanovim koja su pitanja zanimala tužioca i sud, a koja su gen. Mihailoviću postavljena u istrazi - saslušanju i ona koja su mu postavljana kasnije tokom suđenja, ako bih gledao sa pravne strane, mada sam laik, osnovna zamerka je ta što Mihailović nije imao na raspolaganju dokazni materijal koji je imao tužilac, tako da se on u toku suđenja branio odgovarajući na pitanja koja je tužilac Miloš Minić direktno postavljao čitajući dokumenta zaplenjene Mihailovićeve arhive, tako da mislim da je tu već bila uspostavljena jedna neravnoteža u odnosu na osuđenog.

* Rad je deo projekta Srpsko društvo u jugoslovenskoj državi u 20. veku: između demokratije i diktature (177016) koje finansira Ministarstvo prosvete, nauke i tehnološkog razvoja Republike Srbije.

1 Članak predstavlja autorov iskaz pred Prvim osnovnim sudom u Beogradu u procesu rehabilitacije generala Dragoljuba Draže Mihailovića, izrečen 22. juna 2012. Posto je objavljen u elektronskoj verziji na jednom od internet sajtova, privukao je određen broj komentara. Zbog važnosti samog procesa, Redakcija je uvrstila iskaz u sadržaj ovog broja. 
Iz onoga što je raspoloživo, a vezano za suđenje, vidi se da i branioci nisu dobijali tu građu na vreme, nego su je dobijali neposredno pred dan suđenja. Takođe, vidi se iz čitavog sačuvanog materijala da određeni svedoci nisu pozvani, pre svega se misli na predstavnike savezničkih vojski, na one ljude koji su bili u Mihailovićevoj vrhovnoj komandi ili na one ljude vazduhoplovce koje su Mihailovićevi ljudi spasili od zarobljavanja 1944. godine. To je bitno zato što je $\mathrm{u}$ isto vreme u SAD osnovan Komitet za fer suđenje gen. Mihailoviću, koji je takođe izvršio analizu svedočenja i njima raspoložive dokumentacije. Ono što je moj utisak, čitajući arhivsku građu sa suđenja, jeste da su određene teme ili određena pitanja prosto selektovana, da su tužilac i sud u stvari obratili pažnju samo na ono što se tiče partizanskog pokreta. Znači, gotovo da nema nijedne afirmativno izabrane činjenice po Mihailovića.

Takođe, tužilac, a i predsednik veća, prekidali su Mihailovića ili ga skretali sa teme kad god bi njegov tok misli ili ono što je govorio išlo u pravcu nekog objašnjenja kompleksnosti ratne situacije i kompleksnosti vojske kojom je komandovao.

Težište i u istrazi i na sudu bilo je uglavnom ustanovljavanje ravnogorskih zločina prema pripadnicima partizanskog pokreta, uglavnom u Srbiji. Zatim, kolaboracija sa italijanskim snagama u periodu između januara 1943. i juna 1943. u borbama protiv partizana i učešće Mihailovićevih snaga zajedno sa nemačkim i drugim okupatorskim i snagama srpske Vlade u sprečavanju partizanske grupacije da prodre u Srbiju između marta 1944. i septembra 1944. u nekoliko navrata. Mihailoviću su postavljana pitanja na bazi dokumenata koja je tužilac imao, koja su u principu taktičke prirode, znači ne za odnose njegove sa ratujućim snagama ili sa možda protivnicima, nego uglavnom nešto što je kontekst dešavanja na samom terenu, a čega on nije bio svestan. Ovo su glavne, reklo bi se, okosnice oko kojih se fokusirala i tužba i istraga. Takođe, vrlo detaljno je ispitivan Mihailović oko odnosa sa partizanskim snagama u jesen 1941. godine u toku ustanka u Srbiji i njegove eventualne veze sa srpskom Vladom gen. Milana Nedića.

Takođe, u toku suđenja, a i u toku istrage, Mihailoviću su prezentirana tri dokumenta za koja je iz naknadne istoriografske obrade jasno da je reč o falsifikatima, a i on sam je u istrazi i na suđenju odbio da su to dokumenta koja je on potpisao, a to je veoma važno zato što dva dokumenta su njegova navodna pisma hrvatskom poglavniku Paveliću i nadbiskupu zagrebačkom Alojziju Stepincu, oba datirana u martu 1945. godine.

Mihailović je dakle i u istrazi i na sudu odbio da je potpisao ta dva dokumenta, ali u optužbi na kraju po kojoj je streljan su uneti i fakti iz tih pisama da je Mihailović sarađivao sa vlastima u Zagrebu. Treće pismo, tj. dokument koji je falsifikovan a koji nije prikazan $\mathrm{u}$ istrazi a jeste u toku suđenja je njegova navodna naredba svojim komandantima u Crnoj Gori datirana sa čini mi se 20. decembrom 1941. godine po kojoj je faktički on dozvolio mogućnost da se vrše određeni zločini protiv pripadnika komunističkog pokreta i drugih nacionalnosti na tom prostoru severa Crne Gore. 
Ovo je veoma značajno jer je taj dokument često kasnije u istoriografiji stavljen kao početni u onome što se dešavalo na prostoru Crne Gore i Sandžaka kao faktički Mihailovićeva direktiva da se krene u istrebljenje svojih ideoloških protivnika i u bratoubilački rat. Mihailović je, dakle, odbio da je napisao isti i pored diskusije sa tužiocem ostao je čvrst u tome da to nije njegov dokument. U heurističkoj analizi tog dokumenta pojavljuje se nekoliko činjenica koje osporavaju taj dokument kao autentičan. Pre svega saznanje da je Mihailović davao svojim komandantima van Srbije blanko potpisana dokumenta odnosno blanko potpisane papire od kojih su i dan danas neki sačuvani u arhivu, zatim dokument je datiran sa vremenom kada Mihailović to nije mogao da napiše niti da pošalje svojim komandantima u Crnu Goru jer se 20. decembra 1941. godine krio od nemačke potere negde na prostoru između Ravne Gore i Gornjeg Milanovca i nije imao radio komunikaciju ni sa jednim od svojih komandanata. To se takođe vidi i u brojevima depeša koje su poslate u tom periodu i gde se jasno uočava prekid između 6. decembra 1941. i čini mi se 7. januara 1942. godine. Upravo 6. decembar 1941. nemačke snage su izvele operaciju „Mihailović“, uništile njegovo sedište na Ravnoj Gori i zarobile veći broj njegovih oficira i porodice. Takođe, iz iskaza u istrazi i druge komunikacije koja je ostvarivana radio vezom 1942. godine vidi se da Mihailović nije poznavao komandante u Crnoj Gori pa im nije izdavao nikakva naređenja do tad, vidi se da je dokument potpisan sa činom đeneralštabni general što u tom trenutku Mihailović nije znao da je bio unapređen $\mathrm{u}$ čin generala i sva dokumenta sa tim činom je potpisivao mesec dana kasnije.

Dakle, postoje tri dokumenta koja su falsifikovana a upotrebljena su za izvođenje određenih zaključaka na sudu. Mihailović je u slučaju ova druga dva dokumenta odbio autorstvo i u istrazi i na samom sudu kada su mu ta pisma prezentirana. Čini mi se i da je jedan od članova sudskog veća koji je bio pukovnik jugoslovenske armije, a Hrvat je bio, pitao u svojoj knjizi kasnije odakle sudu ta pisma kada su ona upućena Stepincu i Paveliću. Mihailović je označio jednog od svojih saradnika u tom trenutku Brašića kao čoveka koji je možda falsifikovao ova pisma, ali za razliku od ovog prethodnog dokumenta upućenog crnogorskim komandantima meni su ova dva značajnija zato što je na kraju suđenja Mihailoviću ustanovljeno da je on u svojoj borbi protiv partizanskog pokreta lično sarađivao sa vrhom NDH, što ne stoji.

Okolnosti oko tog suđenja ima zaista mnogo, verovatno da bi neka pravna analiza dala određeni sud o tome, sami branioci Mihailovića - advokati Đonović i Joksimović su dali jednu veoma odlučnu, meni se čini, pravno utemeljenu odbranu, zbog koje je advokat Joksimović na kraju i završio u zatvoru gde je umro 1949. godine. Meni je iz Joksimovićeve odbrane najviše ili najadekvatnije došao njegov stav da se Mihailoviću sudi na neki način po komandnoj odgovornosti i analogno suđenju u Nirnbergu, a da pri tom nijednim zakonskim aktom nove Jugoslavije ta pravna procedura koja je korišćena u Nirnbergu nije prihvaćena u jugoslovenskom zakonodavstvu. Ovo je, čini mi se, bilo veoma efektno 
zato što već sutra ili preksutra u „Politici“ tadašnjoj su se javili neki advokati koji su ušli u polemiku sa Joksimovićem oko ovog pitanja.

Ono što bi moglo da bude zaključna rečenica, a neka bude početna, gen. Mihailović u toku rata nije napravio nijedan sporazum sa bilo kojom protivničkom stranom. Dakle, on je vodio ostatke jugoslovenske vojske koje su u početku nazivali Vojno-četnički odredi jugoslovenske vojske, kasnije Jugoslovenska vojska u otadžbini, a zašto u otadžbini - jer je postojao segment van otadžbine, u Egiptu, na Mediteranu, koju su sačinjavali pripadnici vazduhoplovstva, mornarice i kraljeve garde. Takođe, računalo se da zarobljeni pripadnici jugoslovenske vojske koji su bili u logorima u Trećem rajhu takođe pripadaju Jugoslovenskoj vojsci na čijem je čelu bio Mihailović. Ovo govorim zbog toga da bi se shvatilo da je Mihailović 1941. godine bio jedini preostali aktivni učesnik odnosno komandant jugoslovenske vojske i da je kao takav od jeseni 1941. godine priznat od Vlade, a već od početka 1942. godine bio naimenovan za ministra vojnog u toj Vladi i načelnik štaba Vrhovne komande jugoslovenske vojske. Dakle, ističem da je reč o čoveku koji je bio lider jednog pokreta otpora, ali da je skoro tri godine vršio dužnost i načelnika štaba Vrhovne komande i ministra vojnog i bio predstavnik legalne i legitimne jugoslovenske Vlade. Kao takav on je morao da pazi i pazio je sa kim i u kakvoj situaciji razgovara i stoga proizilazi njegov odnos i prema neprijateljima i prema drugim stranama na terenu.

Na samom suđenju Mihailović je odbacio optužbe za ličnu kolaboraciju i kolaboraciju svoje organizacije u odnosu na okupatorske snage dajući jedan širi kontekst tih ratnih događaja koji se vidi ne samo iz suđenja nego i iz sačuvane arhivske građe Mihailovićeve vojske, ali još više njegovih protivnika, pre svega nemačkih vojnih i policijskih organa. Iz te građe iz konteksta događaja vidi se Mihailovićev antiokupatorski stav u toku celog rata. On je i kroz svoje naredbe i ono što je govorio i proklamovao i taj stav nedvosmisleno zastupao - to je borba protiv okupatora koja je imala različite faze u zavisnosti od ishoda na terenu.

I sami okupatori u Srbiji pogotovo nemački komandanti, komandant Jugoistoka kao nadležni za područje najvećeg dela okupirane Jugoslavije, takođe su izražavali neprijateljski stav prema Mihailoviću u onome što potvrđuju dokumenta a datirano je između leta 1941. i jeseni 1944. godine. Znači, obe strane, i Mihailović i Nemci kao glavna okupatorska sila na prostoru okupirane Kraljevine Jugoslavije, imaju međusobni neprijateljski stav, bar sudeći prema dokumentima.

Mihailovićev stav prema nemačkom okupatoru je bio neprijateljski u 1941. godini tako što je on organizovao svoje snage pokreta otpora i zajedno sa od komunista predvođenim partizanima ušao u ustanak krajem avgusta 1941. godine. Tenzije između dva pokreta otpora, da ih tako nazovemo, vide se od početka, njihova saradnja je na terenu u zapadnoj i centralnoj Srbiji, ali raskid nastaje onog trenutka kada Nemci primenjuju drastične represalije da bi smirili ustanak. Bez razumevanja efekata represalija koje su nemački vojni organi sproveli u Srbiji 1941. godine ne može se razumeti ni Mihailovićev odnos prema Nemcima, ali ni formiranje srpske Vlade gen. Nedića. 
Dakle, represalije koje su nemački vojnoupravni komandanti uveli u Srbiji da bi smirili ustanak proizvele su veliki broj civilnih žrtava, potpuno nepotrebnih po shvatanju Mihailovića. Taj broj se merio desetinama hiljada. Nemački podaci vojnoupravnog komandanta Srbije iz februara 1942. godine, kažu da je ta brojka streljanih za odmazdu preko 30.000, a njihovi zbirni podaci iz, čini mi se maja 1942. godine, koji uključuju i događaje u Srbiji i istočnoj Bosni, jer je to deo iste antiustaničke operacije, kažu da je ubijeno, što u operacijama, što u odmazdi (a to se računa pet ili šest puta više) - 49.750 ljudi, ne računajući i jevrejske žrtve koje su takođe u tom vremenu likvidirane za odmazdu. Bez razumevanja konteksta represalija koje su svoj vrhunac imale u oktobru 1941. godine, kada su izvršena streljanja u Kragujevcu, prethodno u Kraljevu i Mačvi, nije moguće razumeti zašto se Mihailović odlučuje da zaustavi svoje snage u toku ustanka i da se okrene borbi sa partizanima.

Pre tog sukoba najmanje dva sastanka sa partizanskim vrhovnim komandantom, koji je ujedno bio i šef KPJ, a koja je bila zabranjena u Kraljevini Jugoslaviji prethodnih 20 godina, dakle organizovana su najmanje dva sastanka pre $\mathrm{i}$ jedan sastanak posle izbijanja neprijateljstva. Ono što se vidi iz nemačkih dokumenata u tom periodu jeste da nemački vojni organi razlikuju od komunista vođene partizane i Mihailovićeve snage kao dve antinemačke ustaničke organizacije. Takođe razlikuju one nacionalne odrede koji nisu bili jednaki sa Mihailovićevim snagama, a bili su protiv komunista i potom vezani za Vladu gen. Nedića.

Dakle, nemački dokumenti jasno definišu Mihailovićevu organizaciju uz komunističku kao ustaničku i oni to i vide u borbama između kraja avgusta i kraja oktobra 1941. godine, Mihailovićeve snage aktivno učestvuju u borbama protiv nemačkih grupa. Taj prvi susret između Mihailovića i predstavnika nemačkih vojnoupravnih vlasti u Srbiji koji se odigrao 11. novembra 1941. godine u kafani u selu Divci kod Valjeva bio je organizovan na traženje određenih predstavnika nemačke vojnopolicijske uprave koji su došli u kontakt sa određenim Mihailovićevim ljudima. Mihailović kaže da je nevoljno otišao pa taj sastanak gde je izložio svoj antikomunistički stav, a da su mu nemački predstavnici zatražili da odmah pristupi razoružanju i kapitulaciji svojih snaga jer će u protivnom snositi posledice tako da, iako je tom sastanku pridavan veliki značaj u partizanskoj propagandi i potonjoj istoriografiji, Mihailović je u stvari iz tog sastanka izašao sa jednom nemačkom pretnjom i vratio se na sedište na Ravnoj Gori, koje su potom 6. decembra nemačke snage zauzele u operaciji nazvanoj „Poduhvat Mihailović““.

Mihailović nije imao daljih kontakata sa bilo kojim od predstavnika nemačkih vojnih, policijskih ili upravnih vlasti do jeseni 1944. godine kada je na zahtev člana američke vojne misije, koji je bio u Mihailovićevom štabu, (a misija je bila obaveštajna jer je predstavnik bio iz službe OSS), dakle na zahtev američkog pukovnika Mekdauela koji je bio u štabu stupilo se u kontakt sa opunomoćenikom nemačkog Ministarstva spoljnih poslova čini mi se, opunomoćenik za okupiranu Srbiju Herman Nojbaher, na prostoru Srbije koji je došao u Srbiju u jesen 1943. godine i promovisao jedan drugačiji stav nemačkih političkih vlasti u 
Srbiji, a koji se odnosi na pre svega tolerantniji odnos prema Srbima i ukidanje represalija u odnosu $1: 100$ na $1: 50$.

Dakle, Mekdauel je želeo vezu sa tim predstavnikom nemačke političke vlasti na prostoru Srbije i umesto Nojbahera je u Mihailovićev štab na razgovor stigao pomoćnik Nojbahera koji se zvao Šterker. Sa tim Šterkerom bilo je četiri susreta u jesen 1944. i u proleće 1945. godine i u prvom od th susreta američki pukovnik je tražio da se nemačke vojne snage u Srbiji predaju Mihailoviću jer su počele već sa izvlačenjem iz Grčke, a u jednom od drugih razgovora taj isti Šterker je doneo ponudu nemačkog komandanta Grupe „Armija E“ generala Lera da se preko Mihailovića preda sa svojim snagama saveznicima.

Ako bih karakterisao ova četiri sastanka, to su bili sastanci sa ljudima nižeg vojno-političkog profila, nisu rezultovali nikakvom saradnjom niti bilo kakvim ishodom i ne mogu da se smatraju kao Mihailovićev akt kolaboracije. Prvom sastanku Mihailovića sa Nemcima 1941. godine posredovao je oficir iz nemačkog vojno-upravnog aparata u Srbiji kapetan Jozef Matl, ali njegova uloga u ovome je bila samo posrednička.

Ono što je bitno je da Mihailović nije imao nijedan kontakt ni sa kojim predstavnikom italijanskih okupacionih snaga, niti vojnog ili političkog establišmenta NDH.

Od konteksta za sud može biti značajan odnos gen. Mihailovića prema gen. Nediću. Taj odnos je rezultovao jednim neuspešnim sastankom u leto 1944. godine. Odnos između Nedića i Mihailovića je bio kompleksan, bio je ličan, pre svega iz činjenice da je Nedić kao ministar vojni pred rat Mihailovića kaznio sa 30 dana kućnog pritvora zbog toga što je Mihailović kao načelnik štaba utvrđivanja jedinice koja je bila u Ljubljani poslao svoj predlog da se jugoslovenska vojska reorganizuje po nacionalnom principu. Čini mi se da Mihailović tu kaznu nije nikako mogao da zaboravi i ta kazna je bila ugrađena u njihov odnos, Nedić je znao za Mihailovićevo neraspoloženje, a Mihailović je bio neraspoložen zbog tog pritvora, jer su ratni događaji potvrdili njegova očekivanja.

Nedić je istog dana pošto je preuzeo dužnost šefa Vlade tražio preko svojih predstavnika da tadašnji pukovnik Mihailović dođe u Beograd da bi se dogovorila nekakva saradnja tj. nekakav kontekst međusobnog funkcionisanja, ali i pored poslate propusnice i svega što je trebalo Mihailović nije otišao u Beograd nego njegov pomoćnik, sin vojvode Mišića, major Aleksandar Mišić. Rezultati tog sastanka nisu doveli do saradnje Nedića i Mihailovića, ali posle sloma ustanka deo Mihailovićeve organizacije u Srbiji se tzv. legalizovao u okviru Nedićevih oružanih odreda i tako izbegao uništenje od nemačke kaznene ekspedicije. Mihailović je tolerisao legalizaciju znajući da je to jedini način da svoje ljude spase od uništenja, a kasnije 1943-44. godine ustanovio je da najveći deo Nedićevog vojnog aparata podržava njegov pokret otpora i nije bilo razloga za nekakvim daljim kontaktima sve do leta 1944. godine kada je na insistiranje ljudi iz okoline obojice generala došlo do jednog sastanka u kome je razmatrana mogućnost da dođe do objedinjavanja snaga srpske Vlade i Jugoslovenske vojske u otadžbini u Srbiji, 
pre svega zbog partizanske ofanzive koja je u tim trenucima bila dramatična pretnja za obe te strukture. Nije došlo ni do kakvog sporazuma osim što su u jesen 1944. godine delovi Nedićeve vojne strukture - srpska državna i srpska granična straža - pristupili na kratko Mihailovićevoj Jugoslovenskoj vojsci u otadžbini i zajedno sa njom se povukli u Bosnu.

Međutim, posle sloma u Bosni u decembru 1944. godine bivše Nedićeve snage napustile su Mihailovićevu grupaciju i uz pomoć Nemaca se evakuisale preko Mađarske i Austrije na Slovenačko primorje.

To ističem iz razloga jer se vidi da nikada nije došlo do nekog sjedinjenja tih snaga pa čak i u uslovima obostranog poraza. Mihailović je u proleće 1945. godine imao samo radio komunikaciju sa Dimitrijem Ljotićem koji je bio sa Nedićevim snagama na prostoru Slovenačkog primorja, ali nije pristao na Ljotićeve ideje o povlačenju sa prostora Bosne i Srbije jer je pre svega verovao u zainteresovanost zapadnih saveznika da ne dozvole da KP preuzme političku vlast u Jugoslaviji posle rata i zato je ostao na prostoru na kom je ostao.

Kao što rekoh, Mihailović je imao sastanke sa vođama komunističke partije odnosno partizanskog pokreta samo u 1941. godini u tom vremenu međusobne saradnje, a posle toga sastanaka između njega i drugih predstavnika tog pokreta nije bilo. Ta dva pokreta su od kraja 1941. godine u Srbiji u nepomirljivom neprijateljstvu, a na prostorima Bosne, Crne Gore, Hercegovine, Srpskih Krajina, to je došlo nešto kasnije, 1942. godine, a takođe i u Sloveniji, identičan ili sličan kontekst događaja kao u Srbiji bio je i na prostoru okupirane Slovenije.

Najveći deo korišćene dokumentacije na suđenju su u stvari Mihailovićevi dokumenti koji su zaplenjeni u nekoliko navrata 1944. i 1945. godine i oni su i danas osnova fonda u Vojnom arhivu, fonda koji se zove „Četnička arhiva“. Ono što se vidi iz te komunikacije i to uglavnom radio komunikacije koja traje 1942 44. godine jeste da su u određenim situacijama u toku borbi pre svega sa partizanima Mihailovićevi komandanti i oni koji su priznavali njegovu vlast, mislim pre svega na one koji su bili van Srbije, odlučivali da sarađuju sa okupatorskim snagama. To možemo okarakterisati kao neku vrstu taktičke saradnje koja je bila često iznuđena odnosom sa partizanima.

Jedna od ključnih stvari za razumevanje tog konteksta saradnje Mihailovićevih komandanata je očekivanje Mihailovića, ali ne samo njega nego i italijanskih i nemačkih vojnih komandi na prostoru okupirane Jugoslavije, da će se saveznici iskrcati na dalmatinskoj obali 1943. godine. U skladu sa tim očekivanjem i Mihailović ali i okupatori su prilagođavali svoju strategiju.

Postoje dva nivoa koja su izostala na suđenju. To su, prvo, odluke i naredbe nemačkih i italijanskih komandi o toku tih operacija gde se vidi da oni žele da unište i partizanske ali i Mihailovićeve snage i sklone ih iz zaleđa Jadranske obale, a takođe, postoji veoma detaljno objašnjen i rastumačen kontekst partizanskih pregovora sa nemačkim vojnim komandama na prostoru $\mathrm{BiH}$ i to je pre svega onaj trenutak kada, to je u februaru ili martu 1943. godine, nemačke snage toliko pritiskaju partizanske snage koje se povlače iz zapadne Bosne ka Hercego- 
vini da partizani ne mogu da izdrže taj pritisak. Zahvaljujući činjenici da su zarobili jednog oficira omogućen je kontakt sa predstavnicima nemačkih vojnih komandi na terenu i u Zagrebu gde je dogovoreno da nemačke snage koje su gurale te partizanske snage naprave jednu pauzu i dozvole izvlačenje partizanima uz prećutnu obavezu da partizani izvrše uništenje Mihailovićeve odnosno četničke glavnine na prostoru istočne Hercegovine.

Ovo nije naravno bilo u materijalima za suđenje, ni ovih naredbi po kojima su nemačke i italijanske snage vršile operacije, a pogotovu ovih dokumenata o tzv. martovskim pregovorima koji su smatrani onda nakon toliko godina za jednu od umešnih taktičkih epizoda partizanskog revolucionarnog rata na prostorima Jugoslavije, tako da toga nije bilo u materijalu za suđenje i materijalu po kome je Mihailoviću suđeno, ne vidi se nijedan odnos nemačkih vojnih komandi prema Mihailoviću ili njegovim snagama osim onog najnižeg taktičkog odnosa. Znači izbor dokumenata je takav da se dokumentovala saradnja na pojedinim delovima fronta gde su se nemačke i Mihailovićeve snage dodirivale slučajno ili namerno, tako da generalno u istoriografskoj slici nedostaje kontekst okupatorovog pogleda na Mihailovićeve snage, odnosno nedostajalo je, a toga naravno nije bilo ni na suđenju, iz koga se vidi neprijateljstvo nemačke vojne komande prema Mihailoviću.

Mihailović jeste dobijao od svojih komandanata depeše o taktičkoj saradnji 1943. sa Italijanima, 1944. sa Nemcima, ali on lično tu saradnju nije odobravao. On je smatrao i objašnjavao u drugim naredbama da je to u stvari mogućnost da njegov pokret uništi suparnički partizanski pokret na određenoj teritoriji, spreči njihovo napredovanje i eventualno se popuni municijom, naoruža itd. tako da on jeste znao, a to nije ni sporio na suđenju, da najveći deo njegovih komandanata koji su došli u borbeni dodir sa partizanskim snagama je uglavnom bio prinuđen da sarađuje sa italijanskim, nemačkim ili snagama srpske Vlade ili slovenačkim.

Ono što je važno za razumevanje - heterogenost ili nejednaka rasprostranjenost Mihailovićeve organizacije. Mihailovićeva vojna organizacija u Srbiji i Sloveniji ima elemente jugoslovenske vojske u gerili i ponaša se kao jugoslovenska vojska u gerilskim uslovima. Na prostorima NDH i Crne Gore Mihailovićeve snage ili one snage koje nominalno priznaju njegovu komandu uglavnom su nastale u drugačijim okolnostima.

U Hrvatskoj kao posledica politike terora prema srpskom stanovništvu i upravo zato Mihailovićeve snage na prostoru NDH imaju dominantan taj srpski odbrambeni kontekst gde se najviše bave egzistencijalnim stvarima pa zato najviše sarađuju sa snagama okupatora i sa snagama NDH prave primirja, a u Crnoj Gori nastanak Mihailovićevih snaga je posledica ustanka protiv italijanskog okupatora i potonjih podela na partizane $\mathrm{i}$ „,ove druge“.

Znači, bitno je da različiti konteksti na prostoru okupirane Jugoslavije dovode do toga da je ta saradnja različito motivisana ili različito opravdana. 